Communication

\title{
In-Situ Self-Assembly of Zinc/Adenine Hybrid Nanomaterials for Enzyme Immobilization
}

\author{
Hao Liang ${ }^{\dagger}$, Shanshan Sun ${ }^{\dagger}$, Yan Zhou and Yanhui Liu * \\ State Key laboratory of Chemical Resource Engineering, Beijing University of Chemical Technology, \\ 15 Beisanhuan East Road, Chaoyang District, Beijing 100029, China; starslh@163.com (H.L.); \\ shanshansun3785@163.com (S.S.); zhouyan@mail.buct.edu.cn (Y.Z.) \\ * Correspondence: liuyh@mail.buct.edu.cn; Tel.: +86-10-6442-1335 \\ + These two authors contributed equally to this work.
}

Received: 16 October 2017; Accepted: 27 October 2017; Published: 3 November 2017

\begin{abstract}
In this study, a one-step and facile immobilization of enzymes by self-assembly of zinc ions and adenine in aqueous solution with mild conditions was reported. Enzymes, such as glucose oxidase (GOx) and horseradish peroxidase (HRP), could be efficiently encapsulated in $\mathrm{Zn} /$ adenine coordination polymers (CPs) with high loading capacity over $90 \%$. When the enzyme was immobilized by $\mathrm{CPs}$, it displayed high catalytic efficiency, high selectivity and enhanced stability due to the protecting effect of the rigid framework. As a result, the relative activity of $\mathrm{Zn} /$ adenine nano-CP-immobilized GOx increased by 1.5 -fold at $\mathrm{pH} 3$ and 4 -fold at 70 to $90{ }^{\circ} \mathrm{C}$, compared to free GOx. The immobilized GOx had excellent reusability (more than $90 \%$ relative activity after being reused eight times). Furthermore, the use of this system as a glucose biosensor was also demonstrated by co-immobilization of two enzymes, detecting glucose down to $1.84 \mu \mathrm{M}$ with excellent selectivity. The above work indicated that in-situ self-assembly of $\mathrm{Zn}$ /adenine CPs could be a simple and efficient method for biocatalyst immobilization.
\end{abstract}

Keywords: adenine; enzyme; self-assembly; coordination polymers; immobilization

\section{Introduction}

Enzymes are a typical class of biocatalysts, having been used in a variety of scientific and technical areas. For instance, they have wide applications in the fields of fine and bulk chemicals, foods, pharmaceutical science, cosmetics, textiles and paper industries, due to their high catalytic activity, high selectivity, low toxicity and water solubility [1-6]. However, the disadvantages of free enzymes, including high cost, poor operational stability and challenges in recovery and reuse, have limited industrial applications of enzymes [7]. To solve these issues, immobilization techniques are considered, because binding of free enzymes to supports limits their mobility [8]. What is more, some immobilized enzymes could show more robust activity than free enzymes [9-12].

Conventional immobilization methods are generally divided into four main categories; adsorption, covalent binding, entrapment and cross-linking [13-22]. However, there are several disadvantages in the conventional immobilization methods, such as the lack of effective reusability, difficulties in immobilization, a severe loss of enzymatic activity due to the blocking of the active site of the enzyme, restricted flexibility and mass-transfer limitations between the enzyme and substrate [13]. Therefore, some new methods and materials to immobilize enzymes have been developed.

Coordination polymers (CPs), formed by metal ions and bridging organic ligands, have recently received considerable attention and are considered as new functional composite materials [23-27]. Because of their mild polymerization conditions, porosity and high guest-entrapment efficiency [11], CPs could play important roles in many fields, including catalysis [12], biological detection [28], imaging [29,30], gas storage [31] and drug delivery [32]. 
In nature, biomolecules normally have excellent metal-coordination properties [33]. Up to now, various types of biomolecules, such as nucleotides [34], proteins [35], peptides [36], amino acids [37] and nucleobases [38] have been used as the ligands to construct CPs. It also has been demonstrated that some CPs are capable of adsorbing and entrapping a broad range of molecules, due to their good biocompatibility and porosity [34,39]. Adenine, as an important naturally occurring nitrogen heterocycle present in nucleic acids [40], has multiple possible metal-binding modes [41-43]. It has been reported that adenine could coordinate with $\mathrm{Zn}$ [44], $\mathrm{Au}$ [45], Ag [46], Co [47] or Cu [48] to form $\mathrm{CPs}$ with diversified morphology and structure. However, most of the researchers just studied the structure of these materials, and very few have studied the encapsulating adaptability of CPs and the activity of guests after they were entrapped. What is more, those CPs that have been reported were formed by harsh reaction conditions, complicated syntheses and with high cost [44-48].

In this work, we reported a convenient, efficient and high-capacity immobilization method for enzymes by the entrapment of glucose oxidase (GOx) and horseradish peroxidase (HRP) within $\mathrm{Zn}$ /adenine CPs. We used adenine and zinc in aqueous solution without adding other linkers to form CPs by in-situ self-assembly. Fourier transform infrared spectroscopy (FTIR), X-ray diffraction (XRD), scanning electron microscopy (SEM) and transmission electron microscopy (TEM) were performed to characterize the CPs. After the CPs was confirmed with promising encapsulating capacity, we use them to immobilize enzymes. The enzyme activity, $\mathrm{pH}$ and thermostability of immobilized enzymes were also investigated. The results revealed that the immobilized enzymes showed high catalytic efficiency, enhanced stability and recyclable usability. Besides, a highly sensitive and selective biosensor for glucose was prepared using the $\mathrm{CPs}$ to co-immobilize glucose oxidase and horseradish peroxidase for an enzyme cascade system. The $\mathrm{Zn} /$ adenine CPs were promising for enzyme immobilization.

\section{Results and Discussion}

\subsection{Preparation and Characterization of Zn/Adenine Complexes}

We first tested the in-situ self-assembly of zinc ions and adenine. The synthesis of the $\mathrm{Zn}$ /adenine composite was performed by mixing zinc chloride solution, adenine and 4-(2-hydroxyethyl)-1-piperazineethanesulfonic acid (HEPES) buffer at room temperature. Then, a white solid precipitate quickly appeared. To understand the formation of the coordination complexes, the coordination of $\mathrm{Zn}^{2+}$ and adenine was studied in different concentrations of HEPES (Figure S1a). The amounts of $\mathrm{Zn}$ /adenine composite increased with increasing HEPES concentration (Figure S1b). High HEPES concentration was beneficial to the formation of complexes. The coordination of $\mathrm{Zn}^{2+}$ and adenine was also studied in different $\mathrm{pH}$ and ionic strength. As shown in Figure S1c, the yield of $\mathrm{Zn} /$ adenine composites reached the maximum at $\mathrm{pH}$ 7.8. Low $\mathrm{pH}$ leads to the protonation of adenine [40], which would inhibit the coordination of $\mathrm{Zn}^{2+}$ ions. Then, the self-assembly reaction was performed at different ionic strengths. It could be found that the amounts of $\mathrm{Zn}$ /adenine composite increased with increasing $\mathrm{NaCl}$ concentration (Figure S1d). The solubility of adenine in aqueous solution was weakened in high ionic-strength solutions, and it would intensify the reaction of $\mathrm{Zn}^{2+}$ ions and adenine [34].

To gain a further understanding of the $\mathrm{Zn} /$ adenine composite, we characterized CPs by FTIR, XRD, SEM and TEM. As shown in Figure 1a, the shift of the IR band may suggest coordination interactions between $\mathrm{Zn}^{2+}$ and $\mathrm{N}_{9}$ (from $1418.4 \mathrm{~cm}^{-1}$ in adenine to $1401.2 \mathrm{~cm}^{-1}$ in the coordination polymer) [45]. The $1671.8 \mathrm{~cm}^{-1}$ band of adenine was considered to arise from the $\mathrm{NH}_{2}$ scissoring vibrational mode [45]. The corresponding $\mathrm{NH}_{2}$ IR band of the coordination polymer was observed at $1643.0 \mathrm{~cm}^{-1}$. The shift of the $\mathrm{NH}_{2} \mathrm{IR}$ band could be attributed to the $\mathrm{C}_{6}-\mathrm{NH}_{2}$ coordination with $\mathrm{Zn}^{2+}$. The assignments of FTIR spectra of adenine and $\mathrm{Zn}$ /adenine complexes were listed (Table S1). According to the results of XRD (Figure 1b), no sharp diffraction peaks were observed in Zn/adenine complexes, indicating the amorphous nature of $\mathrm{Zn} /$ adenine complexes. This may be caused by the asymmetric chemical structure of nucleobases and high coordination flexibility of zinc ions [40]. 
The SEM photo (Figure 1c) and TEM photo (Figure 1d) revealed that the microstructure of CPs resembles a stack of nanoparticles. From the images, we also can re-confirm the amorphous nature of the nano CPs. $\mathrm{Zn}^{2+}$ ions and adenine may firstly form nanoparticles, and then these nanoparticles assemble together (Figure S2). Finally, the stoichiometry of $\mathrm{Zn}$ /adenine CPs determined by the titration experiment was adenine: $\mathrm{Zn}^{2+}=1: 2$ (Figure S3). We considered that adenine bridges four $\mathrm{Zn}^{2+}$ ions through the $\mathrm{N}_{3}, \mathrm{~N}_{7}, \mathrm{~N}_{9}$ and $\mathrm{NH}_{2}$ sites, forming a framework structure (Figure 2). This coordination mode is very similar to the one observed by Hui Wei et al. [45].
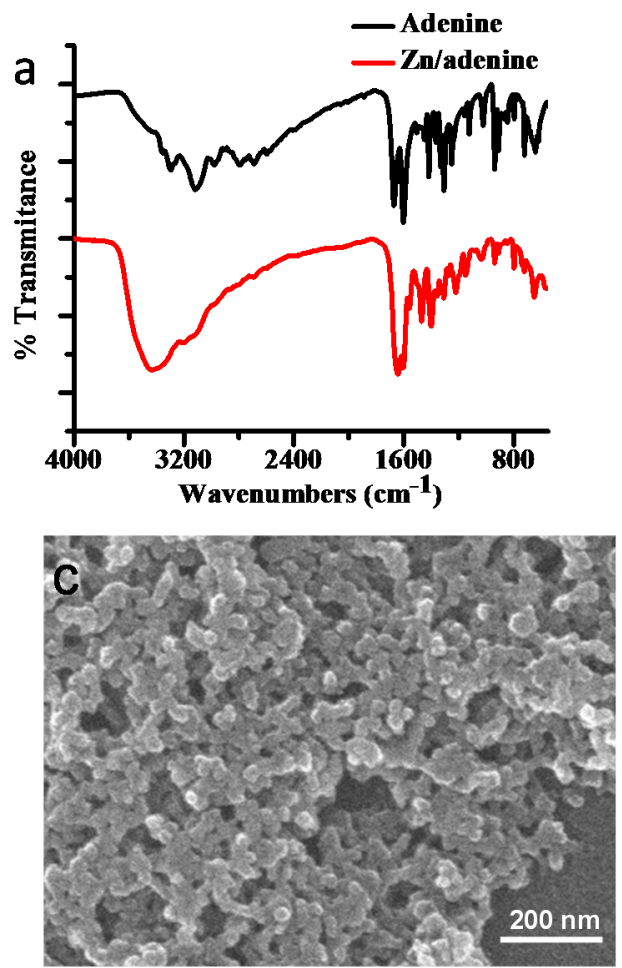
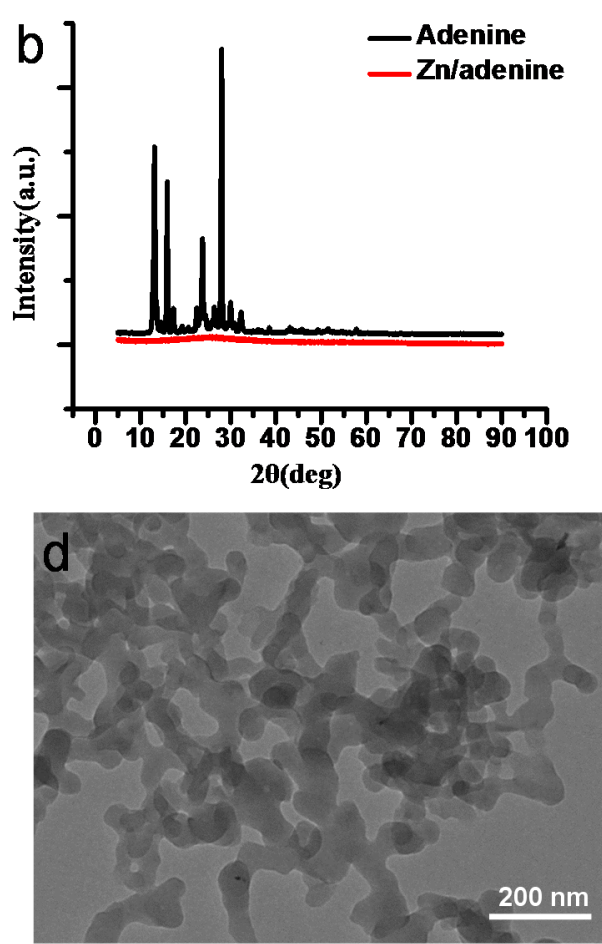

Figure 1. (a) The fourier transform infrared spectroscopy (FTIR) spectra of adenine and Zn/adenine complexes; (b) X-ray diffraction (XRD) patterns of powdery adenine and Zn/adenine complexes; (c) Scanning electron microscopy (SEM) image of $\mathrm{Zn} /$ adenine complexes (magnification = 30,000); (d) Transmission electron microscopy (TEM) image of $\mathrm{Zn} /$ adenine complexes.

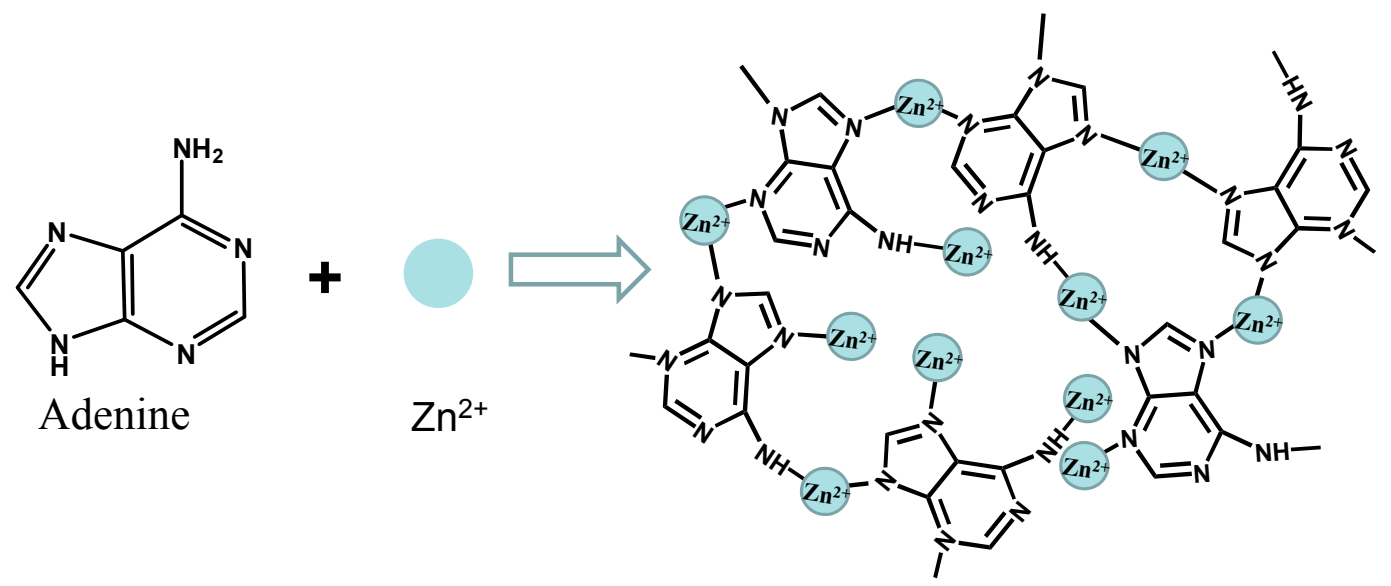

Figure 2. A scheme of $\mathrm{Zn}^{2+}$ reacting with adenine, forming CPs. 


\subsection{Encapsulation Property of Zn/Adenine Complexes}

After confirming the self-assembled properties of $\mathrm{Zn}^{2+}$ ions and adenine, we next tested the in-situ entrapping ability of the composites using three kinds of guests (water-soluble small dyes, proteins and nanoparticles). The encapsulation ratios of guests in nano CPs were calculated by measuring the absorption intensity in the supernatant. All of the guests were encapsulated at a high efficiency (Figure 3a). For water-soluble small dyes, both of the Orange G and Amido black 10B could be encapsulated by the CPs, but the degree was different (Figure 3a). In Amido black 10B, the absorption peak almost completely disappeared in the supernatant, while in Orange $G$ the absorption peak was left at $\sim 30 \%$ in the supernatant (Figure S4). To study the binding capacity of $\mathrm{Zn}^{2+}$ /adenine to proteins, fluorescein-labeled bovine serum albumin (BSA, $\mathrm{pI}=4.7$ ) was next used. As shown in Figure 3a, more than $79 \%$ of BSA was efficiently entrapped. After encapsulating, the fluorescence was almost fully attenuated due to the nano-CP entrapping (Figure S4). This suggested that $\mathrm{Zn} /$ adenine complexes could be able to efficiently encapsulate protein molecules.

The above successes in trapping water-soluble small dyes and proteins prompted us to further investigate nanoparticles as guests. Citrate-capped $13 \mathrm{~nm}$ Au nanoparticles (NPs) were mixed with adenine and $\mathrm{ZnCl}_{2}$. After adding adenine, bluish-violet precipitation formed. The encapsulation ratio of $\mathrm{Au}$ NPs in CPs was calculated by measuring the absorption intensity in the supernatant (Figure S4). There was almost no absorption in the supernatant of $\mathrm{Au}-\mathrm{Zn}$ /adenine complexes, suggesting successful encapsulation. As shown in Figure $3 b$, the entrapped Au NPs could also be observed by transmission electron microscopy (TEM). The round and dark nanoparticles were the Au NPs, which were entrapped by the $\mathrm{Zn}$ /adenine complexes. According to the above results, a diverse range of guest molecules including water-soluble small dyes, proteins and gold NPs could be encapsulated in $\mathrm{Zn}$ /adenine nano CPs with high loading capacity.
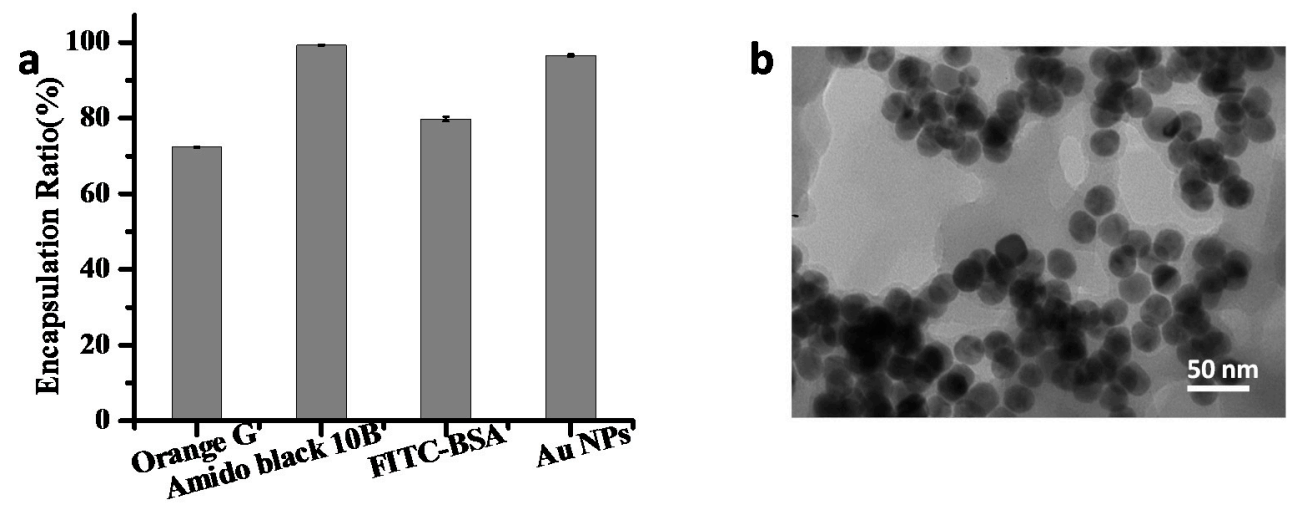

Figure 3. (a) The encapsulation ratios of different guests in the nano CPs; (b) the TEM image of the Au nanoparticles entrapped by $\mathrm{Zn} /$ adenine complexes.

\subsection{Immobilization of Single Enzyme}

Next, we employed glucose oxidase (GOx) and horseradish peroxidase (HRP) as guest molecules to test the enzyme immobilization property of the $\mathrm{Zn}$ /adenine complexes. The loading efficiency of GOx and HRP was $93 \%$ and $92 \%$, respectively (Figure $4 a$ ). In our system, the immobilized enzymes showed about $20 \%$ increase in catalytic activity compared to free enzymes in solution (Figure $4 a$ ). High enzyme stability is important in applications [49-51]. High temperature and extreme $\mathrm{pH}$ are the major reasons for enzyme deactivation. The stability of the GOx-Zn/adenine complexes was examined at different $\mathrm{pH}$ values (from 3 to 10, Figure $4 \mathrm{~b}$ ) and temperatures (from 30 to $90{ }^{\circ} \mathrm{C}$, Figure $4 \mathrm{c}$ ) and compared with that of the free GOx in solution. The activity of the GOx- $\mathrm{Zn} /$ adenine complexes was more stable compared to that of the free enzymes with respect to $\mathrm{pH}$. Especially at $\mathrm{pH} 3$, the immobilized GOx showed a 1.5-fold increase in relative activity compared to free GOx. When the 
temperature was higher, the immobilized enzyme exhibited higher activity compared with the free enzyme. As a result, the relative activity of $\mathrm{Zn}$ /adenine nano CP-immobilized GOx increased by 4 -fold at 70 to $90{ }^{\circ} \mathrm{C}$, compared to free GOx. The confinement of the proteins within the rigid structure of the $\mathrm{CPs}$ prevented protein denaturation caused by thermal fluctuations of proteins in solution [52]. Thus, the $\mathrm{Zn}$ /adenine complexes could protect enzymes from deactivation under heat and acid conditions. We considered that the rigid structure of the nano CPs would increase the structural stability of the embedded enzymes, thus improving the enzymes' stabilities. We also tested the recycling of the GOx-Zn/adenine complexes. The immobilized enzyme can be easily collected by centrifugation after the reaction, and can be redispersed well by vortex mixing. Results indicated that the GOx- $\mathrm{Zn} /$ adenine complexes could reach a relative activity of more than $90 \%$ after being reused eight times (Figure $4 \mathrm{~d}$ ).
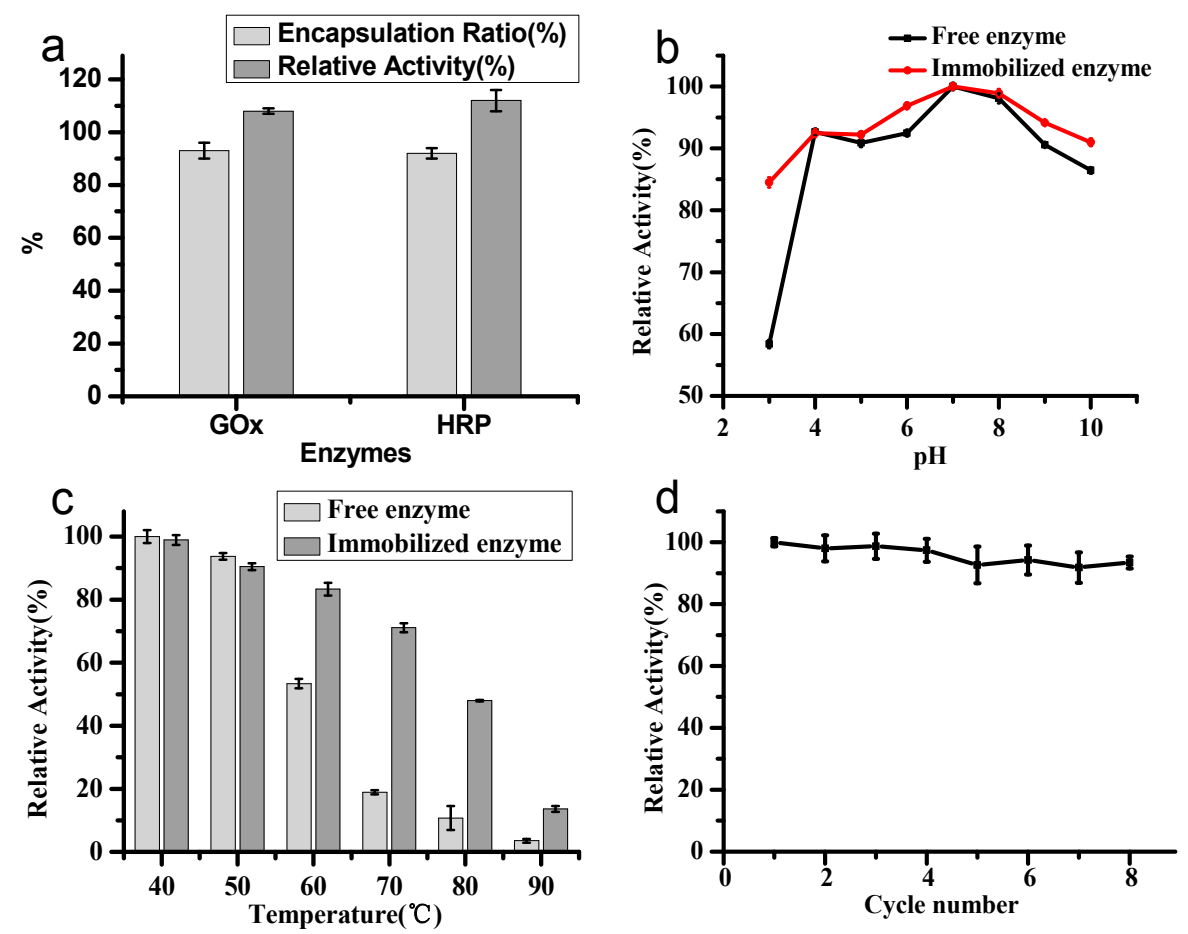

Figure 4. (a) Ratio of encapsulated glucose oxidase (GOx) and horseradish peroxidase (HRP) by the $\mathrm{Zn}$ /adenine complexes, and the relative activity of the two immobilized enzymes compared to the free enzymes; stability of the GOx-Zn/adenine complexes compared with the equivalent free enzymes (b) at different $\mathrm{pH}$ values at $25^{\circ} \mathrm{C}$; (c) at different temperatures; (d) relative activity of GOx-Zn/adenine complexes after reusing for 8 cycles.

\subsection{Co-Immobilization of GOx and HRP}

After establishing the feasibility of using the Zn/adenine complexes for single-enzyme immobilization, co-immobilization of multiple enzymes was further performed. Co-immobilization of multiple enzymes could enhance the overall reaction efficiency and specificity, and omit the isolation of reaction intermediates [10]. GOx specifically converts glucose to gluconic acid and produces $\mathrm{H}_{2} \mathrm{O}_{2}$ as a byproduct, which is a co-substrate for HRP to oxidize 2,2'-azinobis(3-ethylbenzothiazoline-6-sulfonic acid) diammonium salt (ABTS) [52]. Therefore, based on the above studies, GOx and HRP were chosen for a cascade reaction. The total immobilization ratio was over $90 \%$, measured by the Bradford assay. The catalytic activities of the co-localized GOx and HRP in the $\mathrm{Zn}$ /adenine complexes were evaluated by reacting with glucose using ABTS as a chromogenic substrate, and they were compared with the same concentration of free GOx and HRP. However, the relative activity of single enzymes on their own was just half of the activity of the co-immobilized enzymes. The selectivity for glucose was confirmed by monitoring the absorbance at $414 \mathrm{~nm}$ in the presence of various competing compounds (Figure $5 \mathrm{a}$ ). 
Different concentrations of glucose were used to measure the sensitivity of the sensor. Figure $5 b$ illustrates a good linearity between the absorbance and the concentration of glucose in the range of $0-100 \mu \mathrm{M}\left(R^{2}=0.995\right)$. The concentration of limit of detection $C_{\mathrm{LOD}}$ can be expressed as a function of $\mathrm{S}$ (slope of the curve) and $\mathrm{S}_{\mathrm{B}}$ (a standard deviation): $\mathrm{C}_{\mathrm{LOD}}=3 \mathrm{~S}_{\mathrm{B}} / \mathrm{S}$ [35]. In the experiment, $\mathrm{S}_{\mathrm{B}}$ was determined to be calculated by three sets of blank signals, and $S$ was 0.0049 . Calculated according to the formula, the limit of detection (LOD) was determined to be $1.84 \mu \mathrm{M}$, which is lower than some of the previously reported colorimetric glucose sensors [35,53].
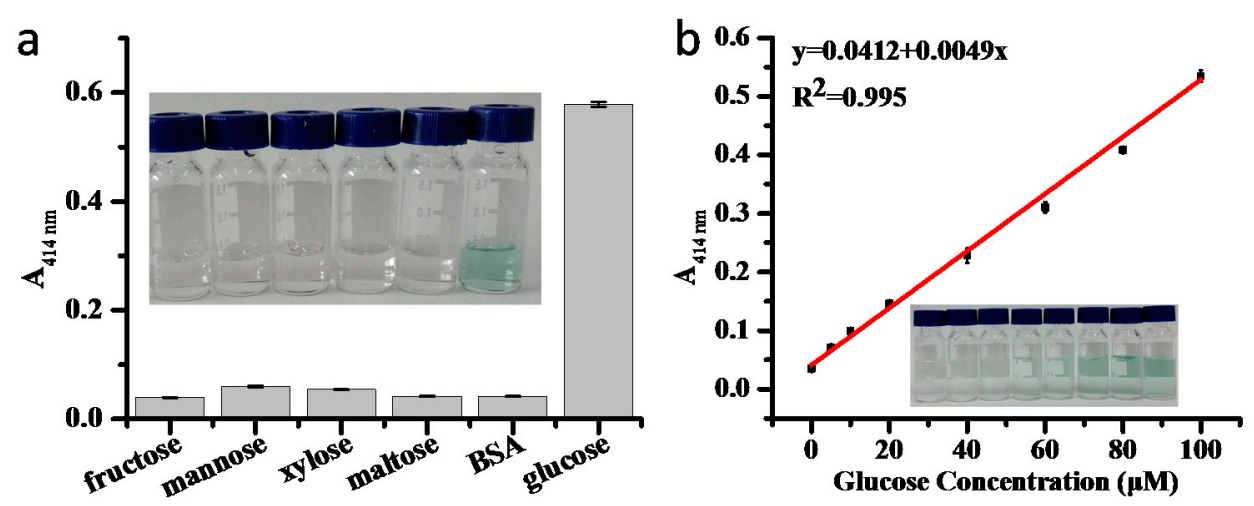

Figure 5. (a) The selectivity of the GOx-HRP-Zn/adenine complexes for $100 \mu \mathrm{M}$ glucose in comparison to $100 \mu \mathrm{M}$ fructose, mannose, xylose, maltose and $1 \mathrm{mg} / \mathrm{mL}$ bovine serum albumin (BSA) (inset: photographs of the samples.); (b) detection of glucose in solutions with glucose concentrations of 0-100 $\mathrm{\mu M}$ (absorbance at $414 \mathrm{~nm}$ was measured after incubation in solution for $10 \mathrm{~min}$ at room temperature) (inset: photographs of the samples).

\section{Materials and Methods}

\subsection{Materials}

Adenine, zinc chloride, sodium chloride, 2,2'-azinobis(3-ethylbenzothiazoline-6-sulfonic acid) diammonium salt (ABTS), $\mathrm{Fe}_{3} \mathrm{O}_{4} \mathrm{NPs}$, 4-(2-hydroxyethyl)-1-piperazineethanesulfonic acid (HEPES), Orange G, Amido black 10B, fluorescein isothiocyanate (FITC), horseradish peroxidase (HRP) and bovine serum albumin (BSA) were purchased from Aladdin Industrial Corporation. $\mathrm{HAuCl}_{4} \cdot 4 \mathrm{H}_{2} \mathrm{O}$ was supplied by Sinopharm Chemical Reagent Co., Ltd. (Shanghai, China). Glucose, fructose, mannose, xylose, sucrose, sodium hydroxide, hydrochloric acid and hydrogen peroxide were purchased from Beijing Chemical Works. Glucose oxidase (GOx) was purchased from Amresco (Scottsdale, AZ, USA). Milli-Q water was used to prepare all the buffers and solutions.

\subsection{Preparation of $Z n$ and Adenine Coordinated Complexes}

In a typical experiment, the $\mathrm{Zn}$ /adenine complexes were prepared by mixing $100 \mu \mathrm{L} \mathrm{ZnCl}{ }_{2}$ (45 mM), $100 \mu \mathrm{L}$ adenine $(15 \mathrm{mM})$ and $500 \mu \mathrm{L}$ HEPES buffer $(100 \mathrm{mM}, \mathrm{pH}$ 7.4). The volume of the system was $1 \mathrm{~mL}$, and water was added to make up. After $2 \mathrm{~h}$ at room temperature, the samples were centrifuged at 10,000 rpm for $5 \mathrm{~min}$ and washed with Milli-Q water to remove remaining chemicals.

\subsection{Study of the Zn/Adenine Complexes at Different Concentrations and $p H$ of Buffer, as Well as Different Ionic Strengths}

Different concentrations of HEPES buffer ( $\mathrm{pH} 7.4,0.1 \mathrm{M}$ ) and different $\mathrm{pH}$ of HEPES buffer were prepared. The $\mathrm{Zn} /$ adenine complexes were prepared by $500 \mu \mathrm{L}$ buffer mixed with $100 \mu \mathrm{L}$ adenine solution $(15 \mathrm{mM})$ and $100 \mu \mathrm{L} \mathrm{ZnCl}_{2}(45 \mathrm{mM})$. To quantify the weight of precipitations, all the samples were centrifuged, dried under $60^{\circ} \mathrm{C}$ and weighed. The content of adenine remained in the supernatant was measured using UV-vis spectroscopy at $260 \mathrm{~nm}$ by the standard curve (Figure S5). The influence of 
ionic strength was also studied. Appropriate $\mathrm{NaCl}$ solution $(2 \mathrm{mM})$ was added into the reaction system to enhance ionic strength. The weight of precipitation and residue ratio of adenine were measured by the aforementioned method. In the experiments, the concentration of HEPES was 10, 20, 30, 40 or $50 \mathrm{mM}$. The different $\mathrm{pH}$ values were $6.8,7.2,7.4,7.8$ or 8.2. The concentration of $\mathrm{NaCl}$ was 100,200 , 300,400 or $500 \mathrm{mM}$.

\subsection{Stoichiometry and Structural Characterization of Zn/Adenine Complexes}

The reaction ratio of adenine obtained by mixing aqueous $\mathrm{ZnCl}_{2}(5 \mathrm{~mL}$ in water) and aqueous adenine $(5 \mathrm{~mL}$ in $0.1 \mathrm{M}$ HEPES buffer at $\mathrm{pH} 7.4)$ was plotted as a function of mixed ratio. Conditions (in reaction mixtures): [adenine] $=1.5 \mathrm{mM},\left[\mathrm{ZnCl}_{2}\right]=0,0.75,1.5,2.25,3.0,4.5,6.0,7.5$ and $9.0 \mathrm{mM}$. It was mixed for about two hours, and centrifuged to separate the supernatant and precipitate. The amount of adenine remained in the supernatant was measured using UV-vis spectroscopy at $260 \mathrm{~nm}$.

Fourier transform infrared spectroscopy (FTIR) spectra of adenine and Zn/adenine complexes were obtained on a FTIR spectrometer (8700/Continuum XL Imaging Microscope, Nicolet, Waltham, MA, USA) with measuring wavelength ranging from 4000 to $550 \mathrm{~cm}^{-1}$.

Powder X-ray diffraction (XRD) patterns of adenine and $\mathrm{Zn}$ /adenine complexes were determined by powder X-ray diffraction (D8 Advance X-ray diffractometer, Bruker, Karlsruhe, Germany) with a $\mathrm{Cu} \mathrm{K} \alpha$ anode $(\lambda=0.15406 \mathrm{~nm})$ at $40 \mathrm{kV}$ and $40 \mathrm{~mA}$.

Scanning electron microscopy (SEM) images of samples were taken on a S-4700 scanning electron microscope (Hitachi, Tokyo, Japan) at an accelerating voltage of $10.0 \mathrm{kV}$. Samples for SEM measurements were prepared by pipetting a drop of the solution of the coordination complexes onto a cover glass and drying on a filter paper.

Transmission electron microscopy (TEM) was performed on a Hitachi H-800 transmission electron microscope (Hitachi, Tokyo, Japan). The sample was prepared by pipetting a drop of the solution of the $\mathrm{Zn} /$ adenine complexes onto a 230 mesh carbon copper grid and drying on a filter paper. The $\mathrm{Au}-\mathrm{Zn}$ /adenine complexes were prepared by the same method.

\subsection{Encapsulation Experiment}

Adenine $(15 \mathrm{mM}, 100 \mu \mathrm{L})$ and dye $(5 \mathrm{mM}, 10 \mu \mathrm{L})$, or fluorescein-labeled bovine serum albumin (FITC-BSA) $(5 \mathrm{mg} / \mathrm{mL}, 10 \mu \mathrm{L})$, or Au NPs $(13 \mathrm{~nm}, 10 \mathrm{nM}, 100 \mu \mathrm{L})$, or $\mathrm{Fe}_{3} \mathrm{O}_{4} \mathrm{NPs}(5 \mathrm{mg} / \mathrm{mL}, 100 \mu \mathrm{L})$ were mixed with HEPES buffer $(0.1 \mathrm{M}, \mathrm{pH} 7.4,500 \mu \mathrm{L})$. Then, $100 \mu \mathrm{L} \mathrm{ZnCl}_{2}(45 \mathrm{mM})$ was added. The products were collected by centrifugation at $10,000 \mathrm{rpm} / \mathrm{min}$ for $5 \mathrm{~min}$. The dyes and Au NPs in the supernatant were quantified using UV-vis spectrometry (UV-2450, Shimadzu). The FITC-BSA in the supernatant was measured by the fluorescence intensity $(485 / 535 \mathrm{~nm})$ by a microplate reader (Infinite F200 Pro, TECAN, Männedorf, Switzerland).

\subsection{Immobilization of Single Enzymes}

The aqueous solution of GOx $(1 \mathrm{mg} / \mathrm{mL})$ and the aqueous solution of HRP $(1 \mathrm{mg} / \mathrm{mL})$ was prepared and stored at $4{ }^{\circ} \mathrm{C}$. Immobilization of the enzymes within the $\mathrm{Zn} /$ adenine complexes was performed by firstly mixing $100 \mu \mathrm{L}$ of $15 \mathrm{mM}$ adenine aqueous solution, $500 \mu \mathrm{L}$ of HEPES buffer $(0.1 \mathrm{M}, \mathrm{pH} 7.4)$, and $100 \mu \mathrm{L}$ of enzymes. Then, $100 \mu \mathrm{L}$ of $\mathrm{ZnCl}_{2}(45 \mathrm{mM})$ in water was quickly added and mixed. After $2 \mathrm{~h}$, the immobilized enzymes were collected by centrifugation at 10,000 rpm for $5 \mathrm{~min}$. The amounts of protein incorporated into the $\mathrm{Zn} /$ adenine complexes were measured by the Coomassie brilliant blue method.

For the GOx activity assay, $200 \mu \mathrm{L}$ of glucose $(20 \mathrm{mM})$ solution and $200 \mu \mathrm{L}$ of ABTS $(0.5 \mathrm{mM})$ were mixed with $20 \mu \mathrm{L}$ of free GOx $(100 \mu \mathrm{g} / \mathrm{mL})$ or $22 \mu \mathrm{L}$ of the suspension of the immobilized GOx (containing the same amount of protein compared with free GOx). Then, $40 \mu \mathrm{L}$ of HRP $(100 \mu \mathrm{g} / \mathrm{mL})$ were added. The mixed samples were incubated at room temperature for $5 \mathrm{~min}$. The reaction was monitored with a UV/vis spectrometer at $414 \mathrm{~nm}$. For the HRP activity assay, $200 \mu \mathrm{L}$ ABTS $(0.5 \mathrm{mM})$ 
and $200 \mu \mathrm{L} \mathrm{H}_{2} \mathrm{O}_{2}(0.9 \mathrm{mM})$ were added into $0.5 \mu \mathrm{g}$ free enzyme and equivalent immobilized enzyme, respectively. The mixed samples were incubated at room temperature for $5 \mathrm{~min}$. The absorbance was recorded at $414 \mathrm{~nm}$.

\subsection{Enzyme Stability Test}

For stability test at different $\mathrm{pH}$ values, the free $\mathrm{GOx}$ and the suspension of GOx- $\mathrm{Zn}$ /adenine complexes were added into $1 \mathrm{~mL}$ of various $\mathrm{pH}$ solutions for $4 \mathrm{~h}$. Then, the enzymatic activity was measured by recording the absorbance at $414 \mathrm{~nm}$. To test stability at different temperatures, free and immobilized enzymes were incubated at $30-90{ }^{\circ} \mathrm{C}$ for $30 \mathrm{~min}$. To test the recycling of the $\mathrm{GOx}-\mathrm{Zn}$ /adenine complexes, the reaction was performed for $5 \mathrm{~min}$, and the immobilized enzyme was separated by centrifugation. The supernatant was measured by recording the absorbance at $414 \mathrm{~nm}$. Then, new substrate and other solution were added to start the new cycle of the reaction for $5 \mathrm{~min}$. The above steps were repeated several times to observe the change of the activity. In all the experiments, the error bars were calculated based on the standard deviation from three independent measurements.

\subsection{Co-Immobilization of GOx and HRP}

Co-immobilization of enzymes within the $\mathrm{Zn} /$ adenine complexes was performed by mixing $100 \mu \mathrm{L} 15 \mathrm{mM}$ adenine aqueous solution with $500 \mu \mathrm{L}$ HEPES (100 mM, pH 7.4). Then, $50 \mu \mathrm{L}$ GOx and $\mathrm{HRP}\left(1 \mathrm{mg} / \mathrm{mL}\right.$ each) were added by vortex mixing. Finally, $100 \mu \mathrm{L} \mathrm{ZnCl}_{2}(45 \mathrm{mM})$ was quickly added and mixed. After $2 \mathrm{~h}$, the immobilized enzymes were collected by centrifugation at 10,000 rpm for $5 \mathrm{~min}$. In co-immobilization, the total immobilized protein ratio (i.e., percentage of immobilized protein) was measured by the Coomassie brilliant blue method.

\subsection{Glucose Detection with GOx-HRP-Zn/Adenine Complexes}

Different concentrations of glucose $(750 \mu \mathrm{L})$ and $1 \mathrm{mM} \mathrm{ABTS}(750 \mu \mathrm{L})$ were added into $500 \mu \mathrm{L}$ of the suspension of GOx-HRP-Zn/adenine complexes. The samples were then incubated at room temperature for $10 \mathrm{~min}$. The reaction solution was centrifuged at 10,000 rpm for $3 \mathrm{~min}$, and the absorbance of the supernatants at $414 \mathrm{~nm}$ was measured by using a UV-1100 spectrophotometer. The selectivity was determined by the absorbance of the supernatants using $100 \mu \mathrm{M}$ glucose as the substrate, compared with $100 \mu \mathrm{M}$ xylose, fructose, mannose, or galactose, or $1 \mathrm{mg} / \mathrm{mL}$ BSA.

\section{Conclusions}

In summary, we presented a one-step, facile and general method for immobilization of enzymes by a typical metal-organic nano coordination polymer. The zinc/adenine hybrid nanomaterials were formed by self-assembly of zinc ions and adenine in aqueous solution with mild conditions. The $\mathrm{Zn}$ /adenine CPs showed a good adaptive encapsulating ability. A diverse range of guests, including water-soluble small dyes, proteins and nanoparticles, could be encapsulated in the nano CPs. All these guests were loaded at a high capacity. Indeed, the loading efficiency of enzymes was over $90 \%$. The GOx-Zn/adenine complexes displayed high catalytic efficiency, high selectivity and enhanced stability due to the protecting effect of the rigid framework. As a result, the relative activity of $\mathrm{Zn}$ /adenine nano-CP-immobilized GOx increased by 1.5 -fold at $\mathrm{pH} 3$ and 4 -fold at 70 to $90{ }^{\circ} \mathrm{C}$, compared to free GOx. Moreover, the immobilized GOx could reach a relative activity of more than $90 \%$ after being reused eight times. The use of this system as a glucose biosensor was also demonstrated by co-immobilization of two enzymes, detecting glucose down to $1.84 \mu \mathrm{M}$ with excellent selectivity. The high sensitivity, stability and recyclable usability of the immobilized enzymes against free enzymes make this method promising for biocatalyst immobilization.

Supplementary Materials: The following are available online at www.mdpi.com/2073-4344/7/11/327/s1, Figure S1: (a) a photograph of $\mathrm{Zn}^{2+}$ reacting with adenine in different concentrations of $\mathrm{pH} 7.4 \mathrm{HEPES}$ buffer. The CP precipitant weight and the adenine percentage remained in the supernatant after $\mathrm{Zn}^{2+}$ reacted with adenine 
and centrifugation of the samples in different concentrations of $\mathrm{pH}$ 7.4 HEPES buffer (b), in different HEPES pH (c) and in different ionic strengths (d); Figure S2: (a) SEM image of Zn/adenine complexes (magnification = 12,000), (b) TEM image of Zn/adenine complexes; Figure S3: The obtained titration curve of the stoichiometry of experiment. Conditions (in reaction mixtures): [adenine] $=1.5 \mathrm{mM},\left[\mathrm{ZnCl}_{2}\right]=0,0.75,1.5,2.25,3.0,4.5,6.0,7.5$, and $9.0 \mathrm{mM}$; Figure S4: UV-vis spectra of Amido black 10B (a) and Orange G (b), and the supernatant after $\mathrm{Zn/adenine-complex} \mathrm{encapsulation;} \mathrm{(c)} \mathrm{Photographs} \mathrm{of} \mathrm{the} \mathrm{samples} \mathrm{of} \mathrm{fluorescein-labeled} \mathrm{bovine} \mathrm{serum} \mathrm{albumin}$ (FITC-BSA) encapsulated in Zn/adenine complexes and the control; (d) UV-vis spectra of the supernatant of Au NPs in HEPES buffer, Au NPs with Zn, with adenine and after Zn/adenine complexes encapsulated (inset: photographs of the samples); Figure S5: The standard curve of adenine with good linearity; Table S1: Assignments of FTIR spectra of adenine and $\mathrm{Zn} /$ adenine complexes.

Acknowledgments: This work was supported by the Beijing Natural Science Foundation (2162030), the Beijing Natural Science Foundation-Beijing Municipal Education Commission Joint Funding project (KZ201710020014), the fund of the Beijing Laboratory for Food Quality and Safety (Beijing Technology and Business University), the National Natural Science Foundation of China (21606014), the Double First-rate Program (ylkxj03) and the 111 Project (B13005).

Author Contributions: Hao Liang, Shanshan Sun, Yan Zhou and Yanhui Liu conceived and designed experiments, analyzed the data, and wrote the manuscript.

Conflicts of Interest: The authors declare no conflict of interest. The founding sponsors had no role in the design of the study; in the collection, analyses, or interpretation of data; in the writing of the manuscript, or in the decision to publish the results.

\section{References}

1. Bornscheuer, U.T.; Huisman, G.W.; Kazlauskas, R.J.; Lutz, S.; Moore, J.C.; Robins, K. Engineering the third wave of biocatalysis. Nature 2012, 485, 185-194. [CrossRef] [PubMed]

2. Choi, J.M.; Han, S.S.; Kim, H.S. Industrial applications of enzyme biocatalysis: Current status and future aspects. Biotechnol. Adv. 2015, 33, 1443-1454. [CrossRef] [PubMed]

3. Kirk, O.; Borchert, T.V.; Fuglsang, C.C. Industrial enzyme applications [review]. Curr. Opin. Biotechnol. 2002, 13, 345-351. [CrossRef]

4. Mateo, C.; Palomo, J.M.; Fernandez-Lorente, G.; Guisan, J.M.; Fernandez-Lafuente, R. Improvement of enzyme activity, stability and selectivity via immobilization techniques. Enzyme Microb. Technol. 2007, 40, 1451-1463. [CrossRef]

5. Tran, D.N.; Balkus, K.J.B., Jr. Perspective of recent progress in immobilization of enzymes. ACS Catal. 2011, 1, 956-968. [CrossRef]

6. Wu, X.; Hou, M.; Ge, J. Metal-organic frameworks and inorganic nanoflowers: A type of emerging inorganic crystal nanocarrier for enzyme immobilization. Catal. Sci. Technol. 2015, 5, 5077-5085. [CrossRef]

7. Cao, S.; Xu, P.; Ma, Y.; Yao, X.; Yao, Y.; Zong, M.; Li, X.; Lou, W. Recent advances in immobilized enzymes on nanocarriers. Chin. J. Catal. 2016, 37, 1814-1823. [CrossRef]

8. Altinkaynak, C.; Tavlasoglu, S.; Ÿzdemir, N.; Ocsoy, I. A new generation approach in enzyme immobilization: Organic-inorganic hybrid nanoflowers with enhanced catalytic activity and stability. Enzyme Microb. Technol. 2016, 93-94, 105-112. [CrossRef] [PubMed]

9. Li, C.; Jiang, S.; Zhao, X.; Liang, H. Co-immobilization of enzymes and magnetic nanoparticles by metal-nucleotide hydrogelnanofibers for improving stability and recycling. Molecules 2017, $22,179$. [CrossRef] [PubMed]

10. Liang, H.; Jiang, S.; Yuan, Q.; Li, G.; Wang, F.; Zhang, Z.; Liu, J. Co-immobilization of multiple enzymes by metal coordinated nucleotide hydrogel nanofibers: Improved stability and an enzyme cascade for glucose detection. Nanoscale 2016, 8, 6071-6078. [CrossRef] [PubMed]

11. Liang, H.; Liu, B.; Yuan, Q.; Liu, J. Magnetic iron oxide nanoparticle seeded growth of nucleotide coordinated polymers. ACS Appl. Mater. Interfaces 2016, 8, 15615-15622. [CrossRef] [PubMed]

12. Lyu, F.; Zhang, Y.; Zare, R.N.; Ge, J.; Liu, Z. One-pot synthesis of protein-embedded metal-organic frameworks with enhanced biological activities. Nano Lett. 2014, 14, 5761-5765. [CrossRef] [PubMed]

13. Brady, D.; Jordaan, J. Advances in enzyme immobilisation. Biotechnol. Lett. 2009, 31, 1639. [CrossRef] [PubMed]

14. Govardhan, C.P. Crosslinking of enzymes for improved stability and performance. Curr. Opin. Biotechnol. 1999, 10, 331-335. [CrossRef] 
15. Kim, J.; Grate, J.W.; Wang, P. Nanostructures for enzyme stabilization. Chem. Eng. Sci. 2006, 61, 1017-1026. [CrossRef]

16. Lei, C.; Shin, Y.; Magnuson, J.K.; Fryxell, G.; Lasure, L.L.; Elliott, D.C.; Liu, J.; Ackerman, E.J. Characterization of functionalized nanoporous supports for protein confinement. Nanotechnology 2006, 17, 5531-5538. [CrossRef] [PubMed]

17. Nadar, S.S.; Rathod, V.K. Magnetic macromolecular cross linked enzyme aggregates (cleas) of glucoamylase. Enzyme Microb. Technol. 2016, 83, 78-87. [CrossRef] [PubMed]

18. Schoevaart, R.; Wolbers, M.W.; Golubovic, M.; Ottens, M.; Kieboom, A.P.; Van, R.F.; La, V.D.W.; Sheldon, R.A. Preparation, optimization, and structures of cross-linked enzyme aggregates (cleas). Biotechnol. Bioeng. 2004, 87, 754-762. [CrossRef] [PubMed]

19. Shah, S.; Sharma, A.; Gupta, M.N. Preparation of cross-linked enzyme aggregates by using bovine serum albumin as a proteic feeder. Anal. Biochem. 2006, 351, 207-213. [CrossRef] [PubMed]

20. Sheldon, R.A. Cross-linked enzyme aggregates (cleas): Stable and recyclable biocatalysts. Biochem. Soc. Trans. 2007, 35, 1583-1587. [CrossRef] [PubMed]

21. Sheldon, R.A.; Van, P.S. Enzyme immobilisation in biocatalysis: Why, what and how. Chem. Soc. Rev. 2013, 42, 6223-6235. [CrossRef] [PubMed]

22. Wang, M.; Bao, W.J.; Wang, J.; Wang, K.; Xu, J.J.; Chen, H.Y.; Xia, X.H. A green approach to the synthesis of novel "desert rose stone"-like nanobiocatalytic system with excellent enzyme activity and stability. Sci. Rep. 2014, 4, 6606. [CrossRef] [PubMed]

23. Cook, T.R.; Zheng, Y.R.; Stang, P.J. Metal-organic frameworks and self-assembled supramolecular coordination complexes: Comparing and contrasting the design, synthesis and functionality of metal-organic materials. Chem. Rev. 2013, 113, 734-777. [CrossRef] [PubMed]

24. Wang, J.; Cohen Stuart, M.A.; Marcelis, A.T.M.; Colomb-Delsuc, M.; Otto, S.; van der Gucht, J. Stable polymer micelles formed by metal coordination. Macromolecules 2012, 45, 7179-7185. [CrossRef]

25. Wang, X.; McHale, R. Metal-containing polymers: Building blocks for functional (nano)materials. Macromol. Rapid Commun. 2010, 31, 331-350. [CrossRef] [PubMed]

26. Whittell, G.R.; Hager, M.D.; Schubert, U.S.; Manners, I. Functional soft materials from metallopolymers and metallosupramolecular polymers. Nat. Mater. 2011, 10, 176-188. [CrossRef] [PubMed]

27. Zhang, W.-X.; Liao, P.-Q.; Lin, R.-B.; Wei, Y.-S.; Zeng, M.-H.; Chen, X.-M. Metal cluster-based functional porous coordination polymers. Coord. Chem. Rev. 2015, 293-294, 263-278. [CrossRef]

28. Tan, H.; Zhang, L.; Ma, C.; Song, Y.; Xu, F.; Chen, S.; Wang, L. Terbium-based coordination polymer nanoparticles for detection of ciprofloxacin in tablets and biological fluids. ACS Appl. Mater. Interfaces 2013, 5, 11791-11796. [CrossRef] [PubMed]

29. Taylor, K.M.; Jin, A.; Lin, W. Surfactant-assisted synthesis of nanoscale gadolinium metal-organic frameworks for potential multimodal imaging. Angew. Chem. Int. Ed. 2008, 47, 7722-7725. [CrossRef] [PubMed]

30. Liu, D.; Huxford, R.C.; Lin, W. Phosphorescent nanoscale coordination polymers as contrast agents for optical imaging. Angew. Chem. Int. Ed. 2011, 50, 3696-3700. [CrossRef] [PubMed]

31. Tran, L.D.; Feldblyum, J.I.; Wong-Foy, A.G.; Matzger, A.J. Filling pore space in a microporous coordination polymer to improve methane storage performance. Langmuir 2015, 31, 2211-2217. [CrossRef] [PubMed]

32. Gao, P.F.; Zheng, L.L.; Liang, L.J.; Yang, X.X.; Li, Y.F.; Huang, C.Z. A new type of ph-responsive coordination polymer sphere as a vehicle for targeted anticancer drug delivery and sustained release. J. Mater. Chem. B 2013, 1, 3202-3208. [CrossRef]

33. Liu, Y.; Tang, Z. Nanoscale biocoordination polymers: Novel materials from an old topic. Chemistry 2012, 18, 1030-1037. [CrossRef] [PubMed]

34. Liang, H.; Zhang, Z.; Yuan, Q.; Liu, J. Self-healing metal-coordinated hydrogels using nucleotide ligands. Chem. Commun. 2015, 51, 15196-15199. [CrossRef] [PubMed]

35. Sun, J.; Ge, J.; Liu, W.; Lan, M.; Zhang, H.; Wang, P.; Wang, Y.; Niu, Z. Multi-enzyme co-embedded organic-inorganic hybrid nanoflowers: Synthesis and application as a colorimetric sensor. Nanoscale 2014, 6, 255-262. [CrossRef] [PubMed]

36. Mantion, A.; Massüger, L.; Rabu, P.; Palivan, C.; McCusker, L.B.; Taubert, A. Metal-peptide frameworks (mpfs): “Bioinspired" metal organic frameworks. J. Am. Chem. Soc. 2008, 130, 2517-2526. [CrossRef] [PubMed] 
37. Imaz, I.; Rubio-Martínez, M.; Saletra, W.J.; Amabilino, D.B.; Maspoch, D. Amino acid based metal-organic nanofibers. J. Am. Chem. Soc. 2009, 131, 18222-18223. [CrossRef] [PubMed]

38. Moussatova, A.; Vázquez, M.-V.; Martínez, A.; Dolgounitcheva, O.; Zakrzewski, V.G.; Ortiz, J.V.; Pedersen, D.B.; Simard, B. Theoretical study of the structure and bonding of a metal—DNA Base complex: Al-guanine. J. Phys. Chem. A 2003, 107, 9415-9421. [CrossRef]

39. Wang, F.; Liu, B.; Huang, P.-J.J.; Liu, J. Rationally designed nucleobase and nucleotide coordinated nanoparticles for selective DNA adsorption and detection. Anal. Chem. 2013, 85, 12144-12151. [CrossRef] [PubMed]

40. Verma, S.; Mishra, A.K.; Kumar, J. The many facets of adenine: Coordination, crystal patterns, and catalysis. Acc. Chem. Res. 2010, 43, 79-91. [CrossRef] [PubMed]

41. Bakkali, H.E.; Castiñeiras, A.; Garcíasantos, I.; Gonzálezpérez, J.M.; Niclósgutiérrez, J. Metallo-supramolecular structures by self-assembly through weak interactions in mixed ligand metal complexes of adenine and malonate. Cryst. Growth Des. 2015, 14, 249-260. [CrossRef]

42. Navarro, J.A.R.; Lippert, B. Molecular architecture with metal ions, nucleobases and other heterocycles. Coord. Chem. Rev. 1999, 185, 653-667. [CrossRef]

43. Singh, P. The family of $\mathrm{n} 9$-adenine: New entry for adenine-benzamide conjugates linked via versatile spacers. J. Chem. Sci. 2014, 126, 159-167. [CrossRef]

44. An, J.; Geib, S.J.; Rosi, N.L. Cation-triggered drug release from a porous zinc-adeninate metal-organic framework. J. Am. Chem. Soc. 2009, 131, 8376-8377. [CrossRef] [PubMed]

45. Wei, H.; Li, B.; Du, Y.; Shaojun Dong, A.; Wang, E. Nucleobase-metal hybrid materials: Preparation of submicrometer-scale, spherical colloidal particles of adenine-gold(iii) via a supramolecular hierarchical self-assembly approach. Chem. Mater. 2007, 21, 2987-2993. [CrossRef]

46. And, C.S.P.; Verma, S. A luminescent silver-adenine metallamacrocyclic quartet. J. Am. Chem. Soc. 2006, 128, 400-401.

47. Burneo, I.; Stylianou, K.C.; Rodríguez-Hermida, S.; Juanhuix, J.; Fontrodona, X.; Imaz, I.; Maspoch, D. Two new adenine-based co(II) coordination polymers: Synthesis, crystal structure, coordination modes, and reversible hydrochromic behavior. Cryst. Growth Des. 2015, 15, 3182-3189. [CrossRef]

48. Garcíaterán, J.P.; Castillo, O.; Luque, A.; Garcíacouceiro, U.; Pascual Román, A.; Lezama, L. An unusual $3 \mathrm{~d}$ coordination polymer based on bridging interactions of the nucleobase adenine. Inorg. Chem. 2004, 43, 4549-4551. [CrossRef] [PubMed]

49. Ge, J. Protein-inorganic hybrid nanoflowers. Nat. Nanotechnol. 2012, 7, 428-432. [CrossRef] [PubMed]

50. Ge, J.; Lu, D.; Liu, Z.; Liu, Z. Recent advances in nanostructured biocatalysts. Biochem. Eng. J. 2009, 44, 53-59. [CrossRef]

51. Kim, J.; Grate, J.W.; Wang, P. Nanobiocatalysis and its potential applications. Top. Catal. 2012, 108, 639-646. [CrossRef]

52. Wu, X.; Ge, J.; Yang, C.; Hou, M.; Liu, Z. Facile synthesis of multiple enzyme-containing metal-organic frameworks in a biomolecule-friendly environment. Chem. Commun. 2015, 51, 13408-13411. [CrossRef] [PubMed]

53. Mu, J.; Wang, Y.; Zhao, M.; Zhang, L. Intrinsic peroxidase-like activity and catalase-like activity of $\mathrm{CO}_{3} \mathrm{O}_{4}$ nanoparticles. Chem. Commun. 2012, 48, 2540-2542. [CrossRef] [PubMed]

(C) 2017 by the authors. Licensee MDPI, Basel, Switzerland. This article is an open access article distributed under the terms and conditions of the Creative Commons Attribution (CC BY) license (http://creativecommons.org/licenses/by/4.0/). 